medRxiv preprint doi: https://doi.org/10.1101/2021.06.13.21258857; this version posted June 15, 2021. The copyright holder for this preprint (which was not certified by peer review) is the author/funder, who has granted medRxiv a license to display the preprint in perpetuity.

It is made available under a CC-BY-NC-ND 4.0 International license .

\title{
Estimating decay curves of neutralising antibodies to SARS-CoV-2 infection
}

\author{
$1^{\text {st }}$ June 2021
}
Megan Poehler ${ }^{1}$, Liam Gibson ${ }^{1}$,Audrey Lustig ${ }^{2,3}$, Nicole J Moreland ${ }^{4,5}$, Reuben McGregor ${ }^{4,5}$, Alex James ${ }^{1,2^{*}}$

1. School of Mathematics and Statistics, University of Canterbury, New Zealand.

2. Te P• naha Matatini: the Centre for Complex Systems and Networks, New Zealand.

3. Manaaki Whenua, Lincoln, New Zealand.

4. School of Medical Sciences, The University of Auckland, Auckland, New Zealand.

5. Maurice Wilkins Centre for Biodiscovery, The University of Auckland, Auckland, New Zealand

\section{*Corresponding author: alex.james@canterbury.ac.nz}

Keywords: immunity, COVID-19, immune response, model

\section{Abstract}

Estimating the longevity of an individual's immune response to the Sars-Cov-2 virus is vital for future planning, particularly of vaccine requirements. Neutralising antibodies (Nabs) are increasingly being recognised as a correlate of protection and whilst there are many studies which follow the response of a cohort of people, each study alone is not enough to predict the long term response. Studies use different assays to measure Nabs making them hard to combine. We present a modelling method which can combine multiple datasets and can be updated as more detailed data becomes available. Combining data from six published datasets we predict that after a short period of rapid decay the half-life of the NAb response is approximately one year giving optimism that the response will be long-lived. 
medRxiv preprint doi: https://doi.org/10.1101/2021.06.13.21258857; this version posted June 15, 2021. The copyright holder for this preprint (which was not certified by peer review) is the author/funder, who has granted medRxiv a license to display the preprint in perpetuity.

\section{Introduction}

As the first waves of Sars-CoV-2 recede a key question in containing the pandemic is the longevity of an individual's immune response to both vaccines and naturally acquired immunity. As of April $27^{\text {th }} 2021$, less than 18 months after the virus was first seen, 1.06 billion doses had been given to over 500 million people. About $7.3 \%$ of the world's population had received at least one dose. However, these figures hide the inequity of the distribution - threequarters of these doses have been received by people in just 10 nations, leaving the remainder spread across the other 170 nations (Kreier, 2021). As second waves of the virus spread across many nations, particularly those with very low vaccination rates like Brazil and India, the need to understand both the body's natural immune response and the vaccine driven response becomes increasingly important. Especially the answer to the key question - How long will immunity last?

New datasets are constantly being released that measure SARS-CoV-2 neutralising antibodies (Nabs): a widely discussed correlate of protection. High titres of Nabs are positively correlated with protection against SARS-CoV-2 challenge in animal models (Chandrashekar et al., 2020) and the presence of neutralising antibodies protected a small number of individuals from re-infection during a SARS-CoV-2 outbreak on a fishing vessel (Addetia et al., 2020).(Khoury et al., 2021) used in vitro NAb data generated from individuals vaccinated or infected with SARS-CoV-2 to show neutralisation levels are highly predictive of immune protection. However, the difficulties posed by combining data generated from assays with different methodologies was highlighted in this modelling study.

Collecting data on an individual's Nabs levels over time is challenging. It may take years for levels to decrease and a wide variation is expected across individuals (Seow et al., 2020). Coupled with this is the dynamics of the response itself. After infection or vaccination Nabs levels tend to increase to a peak then drop slowly. The height of the peak is correlated with the severity of infection (Seow et al., 2020) and can vary by orders of magnitude (Ripperger et al., 2020). Similarly, the timing of the peak may also show a wide range of variation and a delay in Nab production is associated with disease severity (Lucas et al., 2021). Whether the decay rate is also correlated to the disease severity is as yet unknown for SARS-CoV-2. Models can help in understanding the behaviour of the response but with such wide variation between individuals robust methods are needed to make the most of data which currently is still close to the infection date for almost all individuals and, even as time progresses, will require extensive longitudinal follow up of many individuals to get comprehensive data. 
medRxiv preprint doi: https://doi.org/10.1101/2021.06.13.21258857; this version posted June 15, 2021. The copyright holder for this preprint (which was not certified by peer review) is the author/funder, who has granted medRxiv a license to display the preprint in perpetuity.

It is made available under a CC-BY-NC-ND 4.0 International license.

Here we describe a method, which normalises each individuals' response, so the data can be pooled to give a more robust estimate of the decay portion of the response. We start by predicting the antibody response peak for each individual. We compare four response curves and choose the best fit which uses a kinetic response curve. After using the fitted response curve to predict the peak response (time and magnitude) for every individual in the dataset we then normalise each individuals' response around their personal predicted peak. This allows all data collected after the peak response to be pooled for every individual in the dataset. We fit a decay function to the pooled data give a robust estimate of the longevity of the immune response.

Our kinetic response curve for the antibody response has three independent parameters which allow the three key points of the curve: peak timing, peak strength and long term decay rate to be independent. The method can be upgraded to use a more complex response curve at this point, for example to distinguish between the two routes to immunity, vaccination and naturally acquired infection, with subtle differences in the shapes of the response curve. At this stage data following up a large cohort of individuals over many months is not yet available, hence our choice of a very simple response curve which captures the phenomenology of the response and can be used on more sparse datasets.

To estimate the longevity of the Nabs response we compare two very simple decay functions: a single exponential decay and a two-step exponential decay.

We apply our method to six published datasets and compare our results to the published findings. As the method normalises the response data it has a final advantage: data collected using different assays can be collated. This is done under the assumption that the decay function for every individual has the same shape and simply differs in the scale. As further and more detailed data is collected this assumption can be tested.

\section{Data}

We use publicly available data from five recently published papers. Seow et al. (2020) measured the infective dose (ID50) in almost 100 individuals post SARS-CoV-2 infection and showed that the response is similar to that from other acute viral infections, i.e. it shows an initial peak before decaying and the size of the peak is dependent on disease severity. The original work split the group into general cases (labelled Seow here) which included some severe infections, and health care workers (labelled Seow (HCW) here) which predominantly 
medRxiv preprint doi: https://doi.org/10.1101/2021.06.13.21258857; this version posted June 15, 2021. The copyright holder for this preprint (which was not certified by peer review) is the author/funder, who has granted medRxiv a license to display the preprint in perpetuity.

It is made available under a CC-BY-NC-ND 4.0 International license .

90

included mild and moderate cases. Wheatley et al. (2021) measured neutralisation titre and binding inhibition for up to 4 months post infection on 64 participants. lyer et al. (2020) measured neutralisation titre (NT50) responses up to 122 days after infection in 15 patients. Lau et al. (2021) measured plaque reduction neutralization in 195 individuals. Finally, Whitcombe et al. (2021) measured inhibition of the RBD/hACE-2 interaction on 112 patients up to 8 months after infection.

Data from individuals with less than 3 measurements at unique time points were excluded. When multiple replicates on a single day were available the mean value was used. Table 1 gives a brief data summary. The timing of each data point was measured as days post onset of symptoms (POS).

\begin{tabular}{|l|l|l|l|l|l|l|}
\hline Dataset & $\begin{array}{l}\text { Source } \\
\text { (Figure) }\end{array}$ & Participants & $\begin{array}{l}\text { Included } \\
\text { Participants } \\
\text { (>3 data } \\
\text { points })\end{array}$ & $\begin{array}{l}\text { E(number } \\
\text { of data } \\
\text { points })\end{array}$ & $\begin{array}{l}\text { Median } \\
\text { Time } \\
\text { POS } \\
\text { (range) }\end{array}$ & $\begin{array}{l}\text { Measured } \\
\text { response }\end{array}$ \\
\hline Iyer & $(3 a)$ & 15 & 14 & 6.1 & $\begin{array}{l}36.5 \\
(0,75)\end{array}$ & NT50 \\
\hline Lau & $(3 \mathrm{~b})$ & 195 & 17 & 3.6 & $\begin{array}{l}46 \\
(0,194)\end{array}$ & PRNT50 titre \\
\hline Seow & $(2 \mathrm{a})$ & 65 & 47 & 4.6 & $\begin{array}{l}19 \\
(2,94)\end{array}$ & $\begin{array}{l}\text { Neutralising } \\
\text { antibody ID50 }\end{array}$ \\
\hline $\begin{array}{l}\text { Seow } \\
(\text { HCW })\end{array}$ & $(5 a)$ & 31 & 23 & 4.4 & $\begin{array}{l}31 \\
(-9,94)\end{array}$ & $\begin{array}{l}69 \\
(2,149)\end{array}$ \\
\hline Wheatley & $(1 \mathrm{~b})$ & 64 & 29 & 3.4 & $\begin{array}{l}\text { Neutralisation } \\
\text { titre }\end{array}$ \\
\hline Whitcombe & $(3 \mathrm{c})$ & 112 & 23 & 3.5 & $\begin{array}{l}\text { Binding } \\
\text { inhibition }\end{array}$ \\
\hline
\end{tabular}

Table 1: Summary statistics of the datasets. Expected number of data points and median time are for included participants only.

Other similar datasets are available, for example (Ripperger et al., 2020) measured antibody titres over time, though only a very small number of individuals had measurements at multiple times, and fewer were at more than 50 days post symptom onset.

Of the original published works three had fitted models: in (Whitcombe et al., 2021) we fitted a linear decay model to the logged inhibition data of any individual with a decreasing series and reported the mean of these decay rates; Lau fitted a Weibull model to individual time series of logged data and reported the distribution with the mean coefficients; Wheatley et al. 
medRxiv preprint doi: https://doi.org/10.1101/2021.06.13.21258857; this version posted June 15, 2021. The copyright holder for this preprint (which was not certified by peer review) is the author/funder, who has granted medRxiv a license to display the preprint in perpetuity.

It is made available under a CC-BY-NC-ND 4.0 International license.

(2021) fitted a two part linear model to the entire dataset of logged responses, i.e. not to each individual. The approach of Wheatley et al. (2021) assumes each time series only covers the decaying part of the antibody response which can result in misleading results. In particular if any data point for an individual is in the increasing part of the response the predicted decay rate will likely be under estimated, though allowing the model to take two parts does attempt to mitigate this. The method of Whitcombe et al. (2021) to exclude data in the increasing response area avoids this problem but also excludes some data unnecessarily. Our aim is to extend our original model applied in Whitcombe et al. (2021) to provide a method which can give a more accurate picture of the full response curve.

\section{Models}

We tested two types of candidate response curve to fit the time series of each individual's immune response: three statistical and a kinetic model based on simple virus-antibody kinetics. Statistical response curves were derived from a distribution function with an additional parameter to scale the peak of the distribution. They have the advantage of being confined to a very particular set of shapes, in particular the immune response is forced to decrease at some point in time simply by the shape of the function. However, when the data show very little decrease over time this can result in a response curve that is a very poor fit to the data. The kinetic response curve uses a very simple process based approach to describe the interplay between viral load and antibody response. The advantage here is that the resulting function can be more flexible but this in itself can be a disadvantage as it may result in antibody time series that increase! In all cases the response curves were fitted to logged data $(\log . .(\bullet . \cdots \cdots))$ as this provided a significantly better fit in all cases.

Statistical response curves: We tested Gamma, Weibull and lognormal functions. These functions were chosen as they all show an initial, relatively fast, increase then decay more slowly to zero. The Weibull function can demonstrate decay both slower and faster than exponential using variations in the shape parameter. A Gamma distribution is constrained to always show exponential decay after a long time. A lognormal distribution is heavy tailed, i.e. it always shows slower than exponential decay. Each function has two parameters and a third parameter was used to scale the overall size.

Kinetic response curve: We propose an alternative response curve based on virus-antibody kinetics. Any proposed response curve must be simple with very few parameters as each 
medRxiv preprint doi: https://doi.org/10.1101/2021.06.13.21258857; this version posted June 15, 2021. The copyright holder for this preprint (which was not certified by peer review) is the author/funder, who has granted medRxiv a license to display the preprint in perpetuity.

It is made available under a CC-BY-NC-ND 4.0 International license.

individual time series has only three to eight points. By contrast most models of antibody kinetics are highly complex, attempting to describe the interplay of the many different systems at work in an immune response (Thakar, Poss, Albert, Long, \& Zhang, 2010). Our much simpler approach is more suitable for the limited available data. We include two variables $\bullet(\bullet)$ the strength of the antibody response at time $\bullet$ and $\bullet(\bullet)$ a measure of the viral load at time $\bullet$, where $\bullet$ is measured in days. A systematic review including 13 studies that reported viral load in serial upper respiratory tract samples for Sars-Cov-2 (Cevik et al., 2020) found that peak viral load occurred within a week of symptom onset, often soon after or at the time of symptom onset, followed by a constant decline. We assume that viral load has peaked with symptom onset at $\bullet=0$ so $\bullet(0)=1$ and can only decay after this. We assume that initially, when antibody levels are low, viral load will decay more slowly and as antibody levels rise viral load will decay more quickly. This assumption may not always be true, e.g. in serious disease with high viral load there will often be a very high antibody response but the rest of the immune system is overwhelmed so viral load does not decrease in response. However, this response would be at least partially captured by the model through a very low value of - the viral decay rate parameter. These assumptions result in the model

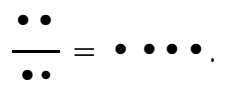

The antibody response level starts close to zero at $\bullet(0)=0.1$ and then increases in response to the size of the viral load. Antibodies also decay exponentially

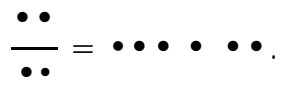

This simple model results in an antibody response function which initially increases before reaching a peak then decays over time. Once the viral load is zero antibody decay is exponential. The strength and timing of the peak are determined predominantly by $\cdot$ and $\bullet$ and the exponential decay rate after the viral load has reached zero is determined by $\bullet$. These three key aspects of the response, i.e. peak strength, timing and decay rate, are all fully independent of each other.

A more complex model would also allow viral load to increase at least initially but this would add at least one more parameter leading to fitting restrictions. It would also likely allow more complex dynamics, in particular where viral load could oscillate over time and possibly never reach zero. Whilst these may, in reality, be possibilities, it would need a very complete time series of measurements to fit a response curve of this type so we do not include this here.

Although the response curve is fitted to antibody responses from natural infection we expect a similar shaped response to vaccination. The viral load variable $\bullet(\bullet)$ would play a different 
medRxiv preprint doi: https://doi.org/10.1101/2021.06.13.21258857; this version posted June 15, 2021. The copyright holder for this preprint (which was not certified by peer review) is the author/funder, who has granted medRxiv a license to display the preprint in perpetuity.

It is made available under a CC-BY-NC-ND 4.0 International license .

role in this case but we would expect the overall antibody response to have a similar shape, i.e. an initial increase which slows as it reaches a peak before decaying exponentially. In this respect the simplicity of the presented response curve is a strength that allows it to give reasonable results despite a different mechanism.

We fit our four candidate response curves to each individual Nabs time series with at least three unique data points. All response curves were fitted using Matlab 2018b 1sqcurvefit. In each case the response function $\bullet(\bullet)$ is fitted to $\log _{10}$ response data and time is measured in days post onset of symptoms (POS). Full fitting results for all 153 individuals including parameter values for every individual are available in Table S1. In the full results we report the maximum inhibition as predicted by each response curve and the timing of the peak, the root mean square error between the fitted response curve and the data for that individual.

\section{Predicting the best fit response curve}

The best fit response curve for each individual's time series is the one which minimises the root mean square error. As all four curves have three parameters we do not need to use AIC or similar to compare. To establish under what circumstances a particular candidate will fit best we use a simple multinomial regression (Matlab 2019b, mnrfit) to predict which of the four curves is a better fit after accounting for the number of points in the series. We also used a general linear model (Matlab 2019b, fitglm) to predict whether the kinetic response curve was a better fit than any of the statistical curves. This allowed us to test the effect of dataset, whether the time series contained any late stage data (more than 3 months POS) or all early stage data (less than 30 days POS) in addition to the number of points

\section{Estimating key outputs: peak size and timing}

We report the median and bootstrapped confidence interval from 1000 samples for all four curves with each dataset separately for the key outputs of peak strength and timing. Whilst it is recognised that the peak size and timing of an antibody response will vary between individuals a good model will include this variation but still give robust estimates of key outputs that are not affected by outliers in the data. We use the size of the predicted confidence interval as a measure of robustness. 
medRxiv preprint doi: https://doi.org/10.1101/2021.06.13.21258857; this version posted June 15, 2021. The copyright holder for this preprint (which was not certified by peer review) is the author/funder, who has granted medRxiv a license to display the preprint in perpetuity.

To compensate for the scarcity of data we normalise each response to allow the data to be pooled. This allows us to meaningfully combine data from individuals to give a more robust estimation of the rate at which antibodies decay. For each model, we normalise each individual's time series using the peak size and time predicted by the response curve for that time series, i.e. the time series peak is shifted to $\bullet=0$ and the maximum antibody response is scaled to 1 for every individual. We then fit a decay function to all the normalised data that is either at or past the time series peak, i.e. during the decay phase (see Figure 1).
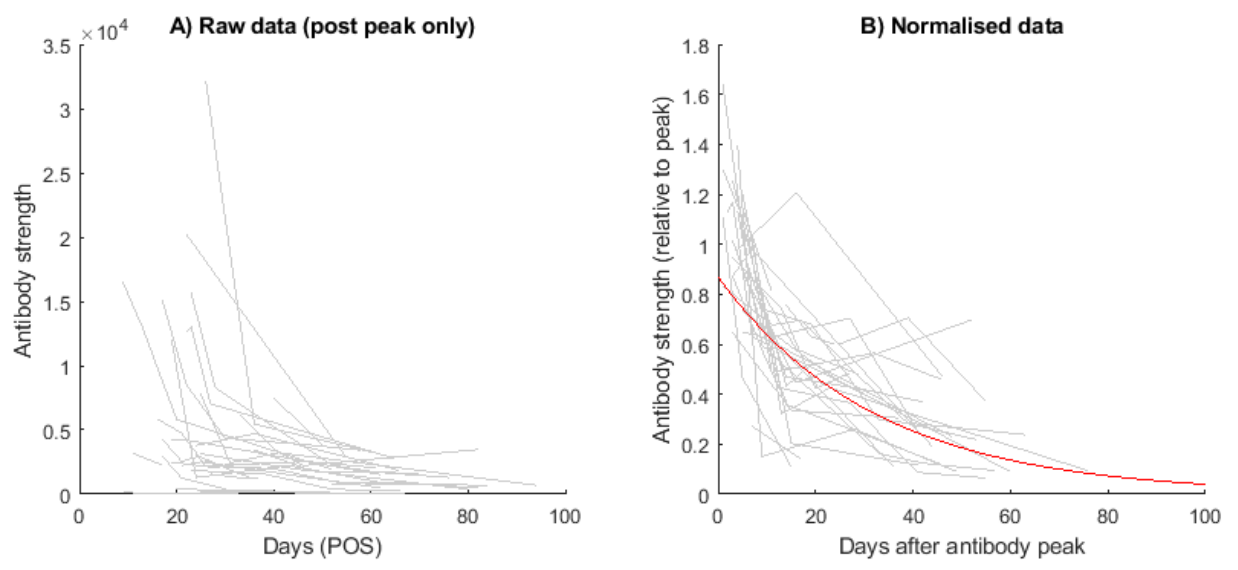

215 Figure 1: An example of the normalisation technique using the Seow dataset and the peak 216 predicted by the kinetic response curve. A) The raw data for each individual for all data points 217 after that individual's predicted peak time only. B) The same data normalised at the response curve predicted peak. The red line shows a single exponential decay curve fitted to all the points in the dataset.

Figure 1 shows an example of the normalising technique using the Seow dataset and the kinetic response curve. Figure $1 \mathrm{~A}$ shows all raw data past the response curve predicted peak, as the data is pooled across all individuals this method can also use data from series with only a single point past the peak. Figure $1 \mathrm{~B}$ scales the raw (unlogged) antibody strength data for individual, $\bullet$, by the response curve predicted peak strength for that individual, $\bullet . .$. , i.e. $\bullet . . .=\bullet / \mathrm{X}^{\bullet} \ldots$... The time data for each individual, $\bullet^{\bullet}$, are shifted using the predicted peak time, $\bullet . \ldots$, i.e. $\bullet . \ldots=\bullet \bullet \bullet .$. . Under this normalisation the response curve of each individual now peaks at 1 at $\bullet=0$. This normalisation does not affect the exponential decay 
medRxiv preprint doi: https://doi.org/10.1101/2021.06.13.21258857; this version posted June 15, 2021. The copyright holder for this preprint (which was not certified by peer review) is the author/funder, who has granted medRxiv a license to display the preprint in perpetuity.

It is made available under a CC-BY-NC-ND 4.0 International license .

229

230

231

232

233

234

235

236

237

238

239

240

241

242

243

244

245

246

247

248

249

250

251

252

253

254

255

rate of the data. Note that for some individuals the first data point after the peak is higher than the predicted peak.

This method can be used with any decay function. We tested two functions: a single exponential function, i.e. linear decay of the logged data, providing a simple half-life estimate that can be compared to other results; and a two part exponential function (cf Wheatley et al. (2021)) which allows an initial period of fast decay followed by slower decay. The simple linear decay was fitted with Matlab 2019b, fitlm, which gives associated p-values of the slope coefficient and Pearson's r-squared. The two part function was fitted with Matlab 2019b, lsqcurvefit.

An advantage of presuming linear decay (on a logged scale) is that when antibodies are assumed to decay exponentially they have an associated half-life, i.e. the time taken for the antibody response to drop by $50 \%$

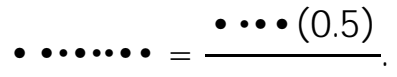

This provides a useful and easy estimate of the longevity of the antibody response and associated immunity.

\section{Results}

Figure 2 shows the time series from each dataset (grey lines) and the smoothed data (black line), Matlab 2019b, smooth. The data average is very prone to noise particularly at the start and end of the time series. The coloured lines show the response curves fitted to each individual smoothed across all individuals. Note that the response curve function evaluated at the median or mean of the fitted parameter values is a different result and not a useful output as it is not necessarily indicative of the average behaviour. It is also encouraging that in regions where there is a reasonable amount of data all the candidate response curves give very similar results. However, when data is scarce, e.g. at very early or late time points, the candidate curves can diverge significantly. This shows the problems with using these fitted curves to directly predict the long term behaviour of the response. 

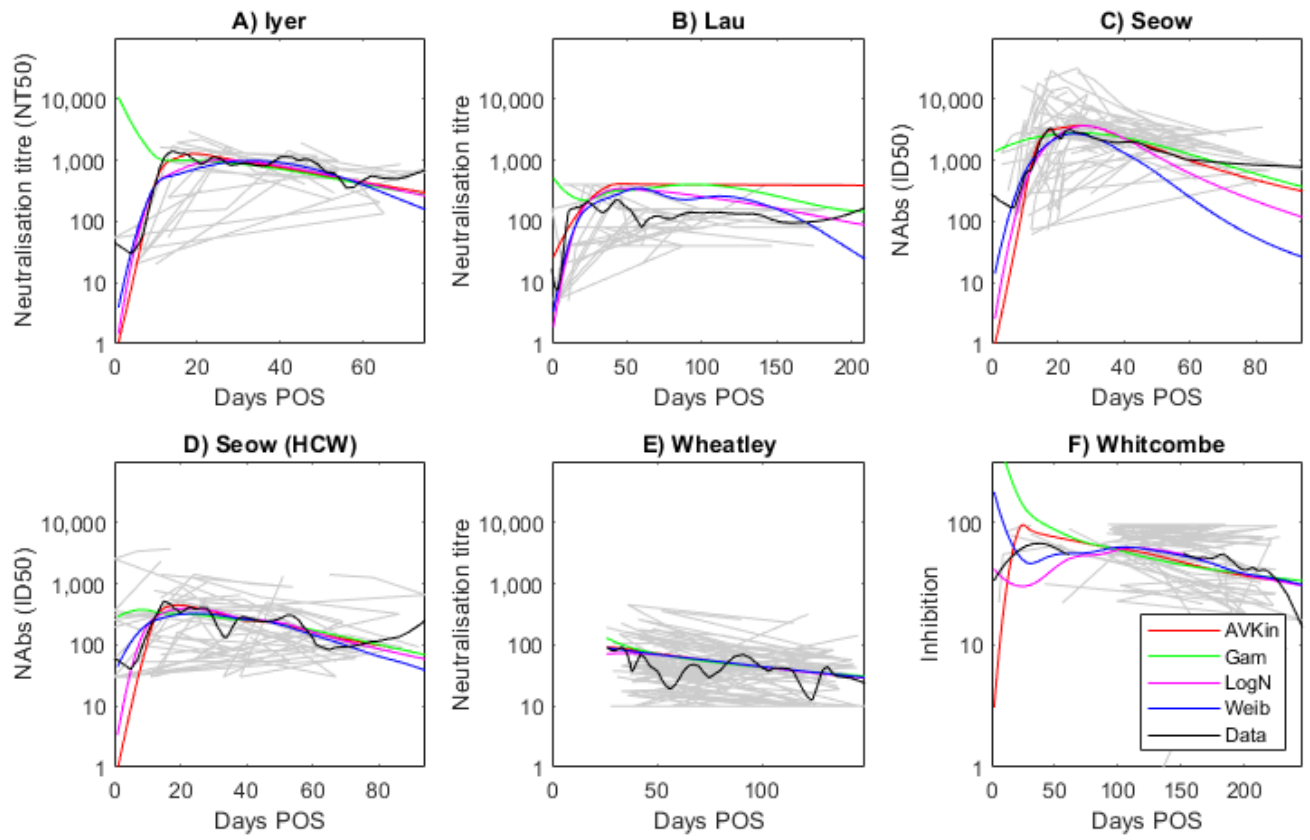

257 Figure 2: Data and fitted immune response curves. Grey lines show the raw time series data.

258 Black line is the smoothed data curve. Coloured lines show the smoothed curves (over all individuals) fitted to individual time series. Smoothing uses robust Loess splines spanning $10 \%$ of the total data points.

The Gamma function gave a poor estimate of these two outputs. It consistently predicted an antibody response that either did not peak within 250 days of symptom onset (excluded from Figures 2 and 3 or peaked at symptom onset, i.e. the best fit function was an exponential where the shape parameter of the Gamma function was equal to 1. The kinetic and lognormal curves give a consistent estimate for the peak antibody strength with a relatively small confidence interval across all six datasets, though the kinetic response curve did fail to predict a decreasing response for 22 time series (14\% of individuals across all 6 datasets), see Table $\mathrm{S} 1$ for details. Peak inhibition (Whitcombe data only) was of the order $100 \%$ and predicted to peak at approximately 20 days post onset of symptoms (kinetic curve). For all other datasets, using the kinetic curve, neutralizing antibody titre was shown to peak between day 18 and day

27330 after onset at which point median peak titre was between 150 (Wheatley) and 4,800 274 (Seow). 

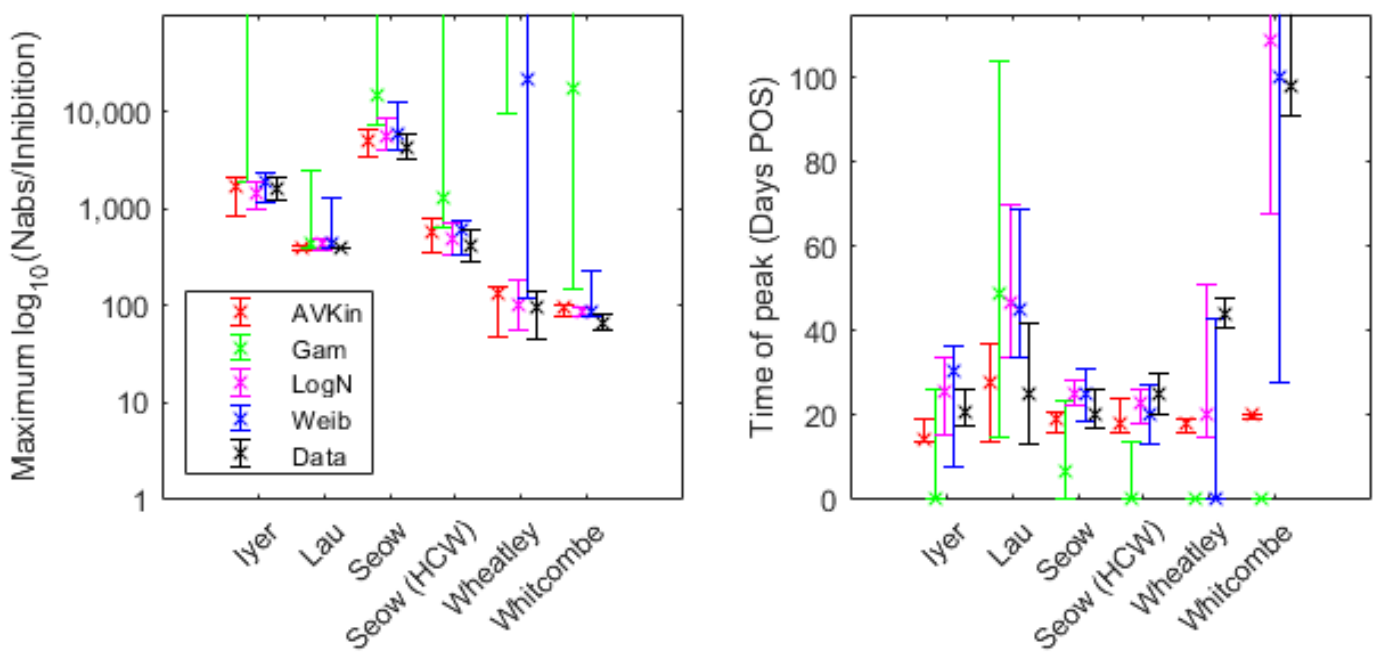

Figure 3: The kinetic and log normal response curves are the most robust across all response strength (as measured by the maximum log(Nabs or inhibition)) and timing for all 6 datasets and four curves. Error bars show a 95\% bootstrapped confidence interval from 1000 samples.

There was no single response curve that was the best fit to the majority of time series (see Table S1 for detailed results). Of the 153 time series fitted the kinetic response curve was the best fit (measured by smallest RMSE) most often (38\%) followed by the Weibull response curve (28\%). However this varied across datasets. In the lyer, Lau and Seow (non-HCW) datasets the kinetic response curve fitted best in the majority of cases, whereas in the Wheatley dataset the gamma function was most frequently the best fit and in the Whitcombe data the Weibull was the best fit most often.

Despite being the most likely best fit in the Wheatley dataset the Gamma function showed poor consistency across all datasets with a very wide confidence interval showing its lack of robustness to outliers. The timing of the peak showed far more variability across all response curves but again the Gamma function was a consistently poor fit with very high variability whereas the kinetic response curve was the most consistent across 5 of 6 datasets. The Gamma function consistently gave very high and unrealistic estimates of the peak antibody response. It also frequently predicted the peak response to occur either before symptom onset or more than 250 days post symptom onset. 
medRxiv preprint doi: https://doi.org/10.1101/2021.06.13.21258857; this version posted June 15, 2021. The copyright holder for this preprint (which was not certified by peer review) is the author/funder, who has granted medRxiv a license to display the preprint in perpetuity.

It is made available under a CC-BY-NC-ND 4.0 International license.

298

299

300

301

302

303

304

305

306

307

308

309

310

311

When we analysed the choice of best fit response curve using both multinomial and logistic regression the only significant variable was the length of the time series. Only very short time series (three points or less) had an inconclusive best fit - the Weibull and Gamma series were almost equally likely in this case. For a series with at least four points the best response curve was the kinetic one. The probability of the kinetic response curve fitting a time series with 4 points best was $37 \%$, this increased to $82 \%$ for a series with 7 points. A logistic regression model where the response variable is either the kinetic response curve is the best fit or any of the statistical response curve is the best fit shows the same result and also predicts that dataset is not a significant variable and the timing of the data collection, i.e. samples were taken either all before the antibody response peak or samples were taken more than 90 days post onset of symptoms, is also not significant. Subsequent analysis was carried out using the kinetic response curve.

Estimating the decay rate of the antibody response

\begin{tabular}{|c|c|c|c|c|c|c|c|}
\hline \multirow[t]{2}{*}{ Dataset } & \multirow{2}{*}{$\begin{array}{l}\text { Published half- } \\
\text { life (days) }\end{array}$} & \multicolumn{3}{|c|}{ Single step decay } & \multicolumn{3}{|c|}{ Two step decay } \\
\hline & & $\begin{array}{l}\text { Decay } \\
\text { rate } \\
\text { (p-value) }\end{array}$ & $\begin{array}{l}\text { Half-life } \\
\text { (days) } \\
(95 \% \mathrm{Cl})\end{array}$ & $\bullet$ & $\begin{array}{l}\text { Decay } \\
\text { rates }\end{array}$ & $\begin{array}{l}\text { Half-lives } \\
\text { (early, } \\
\text { late) } \\
\text { (days) }\end{array}$ & $\begin{array}{l}\text { Change } \\
\text { point } \\
\left(\text { days }{ }^{* *}\right)\end{array}$ \\
\hline Iyer & Not available & $\begin{array}{l}0.023 \\
\left(10^{\bullet \cdot}\right)\end{array}$ & $\begin{array}{l}30 \\
(21,52)\end{array}$ & 0.28 & $\begin{array}{l}0.059 \\
0.013\end{array}$ & $\begin{array}{l}12 \\
52\end{array}$ & 18 \\
\hline Lau & $\begin{array}{l}69 \text { (severe), } \\
87 \text { (mild), } \\
31 \text { (asymp) }\end{array}$ & $\begin{array}{l}0.002 \\
(0.36)\end{array}$ & $\begin{array}{l}345 \\
(107, \cdot)\end{array}$ & 0.03 & $\begin{array}{l}0.025 \\
0.0006\end{array}$ & $\begin{array}{l}27 \\
1134\end{array}$ & 18 \\
\hline Seow & Not available & $\begin{array}{l}0.03 \\
\left(10^{\cdots \cdot}\right)\end{array}$ & $\begin{array}{l}22 \\
(19,27)\end{array}$ & 0.52 & $\begin{array}{l}0.070 \\
0.022\end{array}$ & $\begin{array}{l}10 \\
31\end{array}$ & 14 \\
\hline $\begin{array}{l}\text { Seow } \\
(\mathrm{HCW})\end{array}$ & Not available & $\begin{array}{l}0.024 \\
\left(10^{\cdots \cdot}\right)\end{array}$ & $\begin{array}{l}28 \\
(22,39)\end{array}$ & 0.42 & $\begin{array}{l}0.035 \\
0.011\end{array}$ & $\begin{array}{l}19 \\
60\end{array}$ & 34 \\
\hline Wheatley & $\begin{array}{l}55\left(<\text { day } 70^{*}\right) \\
519(>\text { day } 70)\end{array}$ & $\begin{array}{l}0.0083 \\
\left(10^{\bullet}\right)\end{array}$ & $\begin{array}{l}83 \\
(63,122)\end{array}$ & 0.34 & $\begin{array}{l}0.017 \\
0.0049\end{array}$ & $\begin{array}{l}41 \\
141\end{array}$ & 52 \\
\hline Whitcombe & 146 & $\begin{array}{l}0.01 \\
(0.008)\end{array}$ & $\begin{array}{l}64 \\
(37,235)\end{array}$ & 0.12 & $\begin{array}{l}0.011 \\
0.011\end{array}$ & $\begin{array}{l}65 \\
64\end{array}$ & 21 \\
\hline Combined $^{\dagger}$ & Not available & $\begin{array}{l}0.0049 \\
(10 \cdots \cdots)\end{array}$ & $\begin{array}{l}140 \\
(129,154)\end{array}$ & 0.08 & $\begin{array}{l}0.059 \\
0.0020\end{array}$ & $\begin{array}{l}12 \\
345\end{array}$ & 17 \\
\hline
\end{tabular}

312 Table 2: Decay rate, half-life and Pearson's R-squared for each dataset using each the kinetic 313 response curve for normalisation. Light no significant decay relationship. *Days POS. * Days post response peak. ${ }^{\dagger}$ All datasets excluding Lau. 
medRxiv preprint doi: https://doi.org/10.1101/2021.06.13.21258857; this version posted June 15, 2021. The copyright holder for this preprint (which was not certified by peer review) is the author/funder, who has granted medRxiv a license to display the preprint in perpetuity.

It is made available under a CC-BY-NC-ND 4.0 International license.

315 One dataset (Lau) showed no significant decay after the predicted antibody peak and 316 correspondingly unrealistic half-life estimates (see Table 2). Contrastingly, both datasets by

317 Seow showed high predictive power $\left(\bullet^{\bullet}=0.52,0.42(\bullet \bullet)\right)$.

318 An advantage of the pooled method is that data from different Nabs assays can be collated 319 provided they can be expected to show a similar response shape and half-life. Combining all 320 five significant datasets, i.e. excluding Lau, predicts a half-life of 140 days $(95 \% \mathrm{Cl} 129,153)$ though the predictive power is very poor $\left(\bullet^{\bullet}=0.08\right)$ showing the wide range of variation across individuals.

\section{Discussion}

Of the 5 datasets that showed a significant drop in Nabs post peak antibody response there was a very wide range of predicted half-lives. However, the three datasets with the shortest time range (lyer, Seow, Seow $(\mathrm{HCW})$ ) all predicted much shorter antibody half-lives than the two datasets with a longer time span (Wheatley and Whitcombe). With limited data this may be simply coincidence but it is also consistent with the antibody response not showing a simple exponential decay with a constant half-life.

Using a two-step decay function gave more consistent results in our study. Only one dataset, Whitcombe, did not show a change in decay rate, which may be due to this dataset containing mostly late stage data. The median time to switch from fast to slow decay was 19 days after the peak response and the median half-lives for the fast and slow stages respectively were 23 days and 62 days. When the data sets were analysed together the results were even more optimistic showing a fast stage which lasted for 17 days post peak response with half-life of 12 days then the half-life increased to 345 days. This implies that one and two years after infection antibodies would be at approximately $23 \%$ and $11 \%$ of their maximum level respectively. This is a highly encouraging result and if vaccine immunity follows a similar pattern it gives hope that yearly or even two-yearly booster immunisations could be sufficient to provide long-lasting immunity.

Although our method is tested here with antibody data from individuals who have been infected, it will also be useful for predicting antibody levels after vaccination. The underlying antibody response curve can be updated as more comprehensive datasets become available. 
medRxiv preprint doi: https://doi.org/10.1101/2021.06.13.21258857; this version posted June 15, 2021. The copyright holder for this preprint (which was not certified by peer review) is the author/funder, who has granted medRxiv a license to display the preprint in perpetuity.

It is made available under a CC-BY-NC-ND 4.0 International license.

The biggest assumption of the method presented here is that individuals with a very strong response to the virus will have a similar decay rate as an individual with a much weaker response. More detailed data to test this assumption would allow for a better understanding of the longevity of the immune response. It would also allow for a more detailed understanding of the variation seen between individuals.

The key advantage of the pooled method applied here is the power to combine data from many individuals whilst accounting for the initial increasing phase of the antibody response. As data sets become larger the principle of fitting a simple response curve to predict the antibody peak then normalising the decay phase data against the peak will allow a range of candidates to be tested for the shape of the decay function.

\section{Acknowledgements}

This work was funded by the New Zealand Ministry of Business, Innovation and Employment and Te P•naha Matatini, Centre of Research Excellence in Complex Systems.

\section{References}

Addetia, A., Crawford, K. H., Dingens, A., Zhu, H., Roychoudhury, P., Huang, M.-L., . . Greninger, A. L. (2020). Neutralizing antibodies correlate with protection from SARS-CoV-2 in humans during a fishery vessel outbreak with a high attack rate. Journal of clinical microbiology, 58(11), e02107-02120.

Cevik, M., Tate, M., Lloyd, O., Maraolo, A. E., Schafers, J., \& Ho, A. (2020). SARS-CoV-2, SARS-CoV, and MERS-CoV viral load dynamics, duration of viral shedding, and infectiousness: a systematic review and meta-analysis. The Lancet Microbe.

Chandrashekar, A., Liu, J., Martinot, A. J., McMahan, K., Mercado, N. B., Peter, L., . . Nekorchuk, M. (2020). SARS-CoV-2 infection protects against rechallenge in rhesus macaques. Science, 369(6505), 812-817.

Iyer, A. S., Jones, F. K., Nodoushani, A., Kelly, M., Becker, M., Slater, D., . . Garcia-Beltran, W. F. (2020). Dynamics and significance of the antibody response to SARS-CoV-2 infection. MedRxiv.

Khoury, D. S., Cromer, D., Reynaldi, A., Schlub, T. E., Wheatley, A. K., Juno, J. A., . . Davenport, M. P. (2021). Neutralizing antibody levels are highly predictive of immune protection from symptomatic SARS-CoV-2 infection. Nature medicine, 1-7.

Kreier, F. (2021). 'Unprecedented achievement': who received the first billion COVID vaccinations? Nature.

Lau, E. H., Tsang, O. T., Hui, D. S., Kwan, M. Y., Chan, W.-h., Chiu, S. S., . . Perera, R. A. (2021). Neutralizing antibody titres in SARS-CoV-2 infections. Nature communications, 12(1), 1-7.

Lucas, C., Klein, J., Sundaram, M. E., Liu, F., Wong, P., Silva, J., . . Huang, J. (2021). Delayed production of neutralizing antibodies correlates with fatal COVID-19. Nature medicine, 1-9.

Ripperger, T. J., Uhrlaub, J. L., Watanabe, M., Wong, R., Castaneda, Y., Pizzato, H. A., . . Bime, C. (2020). Orthogonal SARS-CoV-2 serological assays enable surveillance of low-prevalence communities and reveal durable humoral immunity. Immunity, 53(5), 925-933. e924.

Seow, J., Graham, C., Merrick, B., Acors, S., Pickering, S., Steel, K. J., . . Galao, R. P. (2020). Longitudinal observation and decline of neutralizing antibody responses in the three months following SARS-CoV-2 infection in humans. Nature Microbiology, 5(12), 1598-1607. 
medRxiv preprint doi: https://doi.org/10.1101/2021.06.13.21258857; this version posted June 15, 2021. The copyright holder for this preprint (which was not certified by peer review) is the author/funder, who has granted medRxiv a license to display the preprint in perpetuity. It is made available under a CC-BY-NC-ND 4.0 International license .

Thakar, J., Poss, M., Albert, R., Long, G. H., \& Zhang, R. (2010). Dynamic models of immune responses: what is the ideal level of detail? Theoretical Biology and Medical Modelling, 7(1), 17.

Wheatley, A. K., Juno, J. A., Wang, J. J., Selva, K. J., Reynaldi, A., Tan, H.-X., . . Esterbauer, R. (2021). Evolution of immune responses to SARS-CoV-2 in mild-moderate COVID-19. Nature communications, 12(1), 1-11.

Whitcombe, A. L., McGregor, R., Craigie, A., James, A., Charlewood, R., Lorenz, N., . . Fox-Lewis, S. (2021). Comprehensive analysis of SARS-CoV-2 antibody dynamics in New Zealand. Clinical \& translational immunology, 10(3), e1261. 